\title{
NURSING TEAM'S PERCEPTION OF ACCIDENTS WITH SHARP INSTRUMENTS IN THE INTENSIVE CARE UNIT OF A PUBLIC HOSPITAL IN SÃO LUÍS CITY, BRAZIL
}

\author{
Percepção da equipe de enfermagem sobre acidentes com material \\ perfurocortante na unidade de terapia intensiva em um hospital público \\ de São Luís/MA
}

\section{Percepción del equipo de enfermería en accidentes con material afilado en la unidad de atención intensiva en un hospital público en São Luís, Brasil}

Sandra Regina Santos ${ }^{1}$, Cristiane de Oliveira Novaes ${ }^{2}$, Bianca Ramos Marins Silva ${ }^{3}$

How to cite this article:

Santos SR, Novaes CO, Silva BRM. Nursing team's perception of accidents with sharp instruments in the intensive care unit of a public hospital in São Luís city, Brazil. 2020 jan/dez; 12:863-871. DOI: http://dx.doi.org/ 0.9789/2175-5361.rpcfo.v12.7880.

\begin{abstract}
Objective: The study's main purpose has been to describe the nursing team's perception of work accidents with sharp instruments in an intensive care unit of a public hospital in São Luís city, Maranhão State, Brazil. Methods: Data collection took place through interviews with questions about the following subjects: work accidents, handling of sharp instruments, risk perception, use of personal protective equipment, personal and professional expectations after the accident, training in facing health risks, immunization actions, notification of health problems, and educational actions. Results: The results revealed that accidents with needles and blades were most frequent as these are the instruments most used in intensive care units. Conclusion: The interviewees reported the importance of continuing education aiming at a qualified service and improved care practice.
\end{abstract}

Descriptions: Nursing, work accident, intensive care unit.

\section{RESUMO}

Objetivo: Descrever a percepção da equipe de enfermagem sobre acidentes de trabalho com material perfurocortante em uma Unidade de Terapia Intensiva de um hospital público na cidade de São Luís/Maranhão. Métodos: Para a coleta foi através de entrevista com questões sobre: acidentes de trabalho; manuseio de materiais perfurocortantes, percepção do risco; uso de equipamentos de proteção individual expectativa pessoal e profissional em decorrência do acidente; capacitação/treinamento de enfrentamento do risco à saúde; ações de imunização; notificação do agravo à saúde e ações educativas. Resultados: Os resultados revelaram que os acidentes que ocorrem pela exposição aos riscos com agulhas e lâminas são os materiais mais manipulados, em decorrência das atividades laborativas em uma

1 Nursing Graduate, MSc in Health and Technology at the Hospital Level by the UNIRIO, Professor at Instituto Florence de Ensino Superior, Registered Nurse at the University Hospital from São Luís city.

$2 \mathrm{PhD}$ in Public Health and Environment by the Fundação Oswaldo Cruz (FIOCRUZ), Associate Professor at UNIRIO.

$3 \mathrm{PhD}$ in Health Surveillance by the Instituto Nacional de Controle de Qualidade em Saúde (INCQS), Associate Professor at UNIRIO. 
unidade de terapia intensiva. Conclusão: Os entrevistados relataram a importância de ações de educação continuada visando a qualificação em serviço e aperfeiçoamento da prática assistencial.

Descritores: Enfermagem, Acidente de trabalho, Unidade de Terapia Intensiva.

\section{RESUMÉN}

Objetivo: Describir la percepción del equipo de enfermería sobre accidentes de trabajo con material punzocortante en una Unidad de Terapia Intensiva de un hospital público en la ciudad de São Luís / Maranhão. Métodos: Para la recolección fue a través de entrevista con cuestiones sobre: accidentes de trabajo; manipulación de materiales punzantes, percepción del riesgo; uso de equipos de protección individual expectativa personal y profesional como consecuencia del accidente; capacitación / entrenamiento de enfrentamiento del riesgo a la salud; acciones de inmunización; notificación del agravio a la salud y acciones educativas. Resultados: Los resultados revelaron que los accidentes que ocurren por la exposición a los riesgos con agujas y láminas son los materiales más manipulados, como consecuencia de las actividades de trabajo en una unidad de terapia intensiva. Conclusión: Los entrevistados relataron la importancia de acciones de educación continuada visando la calificación en servicio y perfeccionamiento de la práctica asistencial.

Descriptores: Enfermería, Accidente de trabajo, Unidad de Terapia Intensiva.

\section{INTRODUCTION}

Established in 1919, the International Labour Organization (ILO) is the major international reference for organizational labor practices. There is growing concern about the causes of illness and absence from work, with work accidents being the biggest problem for workers' health.

According to Article 19 from the Law No. 8,213/91, amended by Article 19 from the Decree of the Social Welfare Ministry No. 611, July 21st, 1992, a work accident is defined as one that "occurs due to the exercise of work, at the service of the company, causing bodily injury, functional disturbance or illness that causes death, loss, or permanent or temporary reduction of the capacity for work". In the Statistical Yearbook of Occupational Accidents of Social Welfare, prepared by the Finance Ministry and Labor Ministry, from 2013 to 2015, 612,632 accidents at work were registered throughout Brazil, of which 502,942 were with Comunicação de Acidente de Trabalho (CAT) [Work Accident Report]. From these accidents, 383,663 were typical $(76.3 \%)$ : they resulted from the characteristic of the professional activity performed by the insured worker. ${ }^{1}$ The ILO estimates that 2.34 million people die every year as a result of work-related accidents and illnesses. Thus, 5,500 of the 6,300 estimated work-related deaths are caused daily by various types of occupational diseases. ${ }^{2}$

Viral hepatitis caused 1.34 million deaths in 2015, a figure comparable to the deaths caused by tuberculosis and the Human Immunodeficiency Virus (HIV). Although the number of deaths from tuberculosis and HIV has decreased, those from hepatitis are increasing. Approximately 1.75 million people worldwide were infected with the hepatitis C virus (HCV) in 2015, increasing the total number of people living with hepatitis $\mathrm{C}$ to 71 million. $^{3}$
Also, according to this report, in $2015,9 \%$ of hepatitis $B$ virus (HBV) infections and $20 \%$ of $\mathrm{HCV}$ infections were diagnosed. However, $8 \%$ of people diagnosed with $\mathrm{HBV}$ (1.7 million people) were on treatment and only $7 \%$ of those diagnosed with HCV (1.1 million people) started treatment during that same year. Created by the World Health Organization (WHO), the Global Health Sector Strategy for viral hepatitis aims to test $90 \%$ and treat $80 \%$ of people with HBV and HCV by $2030 .^{3}$

In 2017, the WHO improved treatment by expanding access to hepatitis $C$ treatment. It pre-qualified sofosbuvir as an active generic drug. This strategy will allow more countries to produce affordable drugs for hepatitis treatment. ${ }^{3}$

Health care workers are the most exposed professionals. Most of them are nurses due to the continuous and uninterrupted assistance provided intra-hospital units, such as hospital wards, Intensive Care Units (ICUs), and surgical centers; and extra-hospital units, such as outpatient and health care units.

This article meant to describe the nursing team's perception of work accidents with sharp instruments in an ICU of a large public hospital in São Luís city, Maranhão State, Brazil, 2015.

\section{METHODS}

This descriptive study with a qualitative approach was part of the project titled "Accidents with sharp instruments: educational strategies for occupational risk reduction". The study was carried out in an ICU of a large public hospital in São Luís city in 2015. It is a reference hospital in Maranhão State regarding the offer of clinical, surgical, and obstetric services for critically ill adults. The ICU has 15 beds (one of them is an isolation bed) under the care of a multidisciplinary team.

The reference hospital has 16 nurses and 47 nurse technicians. Nevertheless, the sample of this study consisted of 11 nurses and 34 nurse technicians. The inclusion criterion was working in the hospital's ICU. Exclusion criteria were workers on vacation or leave. The interviewees agreed to participate in this study by signing the informed consent document as required by the Resolução da Diretoria Colegiada (RDC) [Resolution of the Collegiate Board of Directors] of the National Health Council/Health Ministry No. 466, December 12th, 2012.

This study was approved by the Research Ethics Committee of the hospital, under the Legal Opinion No. 95/2015 in accordance with the Resolution No. 466. The interviews were conducted from October to November 2015. An interview script was developed with questions addressing the following subjects: work accidents, handling of sharp instruments, risk perception, use of Personal Protective Equipment (PPE), personal and professional expectations after the accident, training in facing health risks, immunization actions, notification of health problems, and educational actions. The interviews were conducted individually. The participants' statements were recorded, transcribed in full, and later grouped into discursive 
categories according to the study objectives. After the transcription step, the statements were labeled using an alphanumeric sequence (P1, P2, etc.).

The collected data submitted to content analysis. This technique is divided into three steps: a) data sorting (fast reading); b) classification (exploration of the material), and c) final analysis (interpretation of the results). ${ }^{12}$ Hence, the transcribed statements were read carefully, seeking to identify convergent and divergent text elements that enabled the construction of the categories for further analysis. These categories were also defined in order to allow the establishment of relationships and the understanding of the study objectives.

\section{RESULTS AND DISCUSSION}

Regarding the participants' profile, most of them were women (78\%) aged from 20 to 50 years. Also, $80 \%$ of the participants had been working in the ICU for 1 to 5 years.

The results of this study are similar to those of another one, which was carried out to understand the nursing team's perspective on the work performed in an ICU of a public hospital in Goiânia city, Goiás State, Brazil. In this case, the majority of the professionals were women (88\%) aged from 36 to 45 years. Of the team members, $78 \%$ were nurse technicians and $61 \%$ had been working in the unit for 1 to 10 years. ${ }^{4}$

Five analysis categories capable of fulfilling the study objective were identified:

\section{Understanding about work accidents}

"I define it as something that was not meant to happen, [...] a fatality that causes harm for the employee, you know, who suffered the accident, [...] which may result in a simple injury or infection with a virus, such as HIV, Hepatitis". (P1)

"The accident can occur due to the colleague's carelessness, as it already happened, [...] when he/she handles sharp instruments without any protection". (P8)

"A work accident happens within the work environment, i.e., it happens during your working hours, [...] it is something that is part of your job". (P18)

As stated by the interviewees, work accidents may occur without an apparent cause. Nonetheless, workers' negligence or even events inherent to the work process may cause accidents. In a study conducted with workers of a university hospital, workers' negligence was pointed out as a key factor for work accidents. ${ }^{5}$

Therefore, the study findings suggested that work accidents were perceived as an "inevitable" outcome, i.e., as something natural and intrinsic to the work process.

\section{Handling of sharp instruments in the ICU}

When asked about the handling of sharp instruments in the ICU, the interviewees pointed out that needles and scalpel blades are the most used ones.

"Needles, scalpel blades; those are the most used, [...] That is what I see". (P10)

"The needles, you know, [...] scalpel blades are also used a lot”. (P12)

"Needles and scalpel blades, you know, [...] we carry out a lot of procedures here". (P14)

"Needles, scalpel blades. We use that stuff a lot". (P20)

The study results are in line with a study conducted in the United States of America, which estimated that 800,000 accidents occurred each year involving the handling of needles and syringes. The damage caused by handling these instruments accounted for more than $80 \%$ of the accidents involving blood. ${ }^{6}$ Needles are considered the predominant instrument by other studies, with needle recapping being the major cause of accidents. ${ }^{7}$

Aiming at reducing the incidence of accidents involving sharp instruments, it is considered that the correct disposal is performed in an adequate container as recommended by the sanitary legislation. This container should be in a visible, easily accessible location to ensure safety for the nursing team according to the Norma Regulamentadora [Regulatory Standard] 32 (NR 32) and RDC No. 306., It is recommended that the waste should be disposed of at $5 \mathrm{~cm}$ from the hole or up to $2 / 3$ of the capacity for proper sealing of the container. As for the container, it must be placed at a height that favors visualization.

Concerning the disposal process and the existence of suitable containers, the participants stated as follows:

"The quantity is even reasonable, [...] the problem is the location (under the medication counter), [...] when it is full, you do not notice it, [...] people keep trying to put more instruments when the box has already reached its limit,(...), then the risk is big”. (P18)

"[...] the quantity is reasonable, [...] sometimes it is missing, [...] what I think is wrong is that it stay in a place with little visibility, [...] it stays under the medication counter, [...] when it is full you cannot even notice it, [...] if you do not pay attention when you go to dispose of it, you may even pierce yourself". (P21) 
According to participants' reports, insufficient quantity and/or inadequate location may increase the risk of work accidents with sharp instruments as it makes correct and safe disposal impossible for all workers.

\section{Professional and personal expectations}

Workers are described as multifaceted, unique, indivisible human beings with biological, psychic, and social dimensions. ${ }^{10}$ Given these dimensions, accidents may have bodily/physical/emotional/social repercussions due to the damage caused by the accident (perforation/ cutting) and adverse effects from medications, especially antiretroviral ones. In this framework, emotions that cause direct implications for the individual's life are made explicit and/or mobilized.

So, the following reports evidenced the interviewees' emotions after the accident:

"[...] I had just collected blood for blood culture, [...] I felt the needle through the glove, [...] I thought it was just a scratch, [...] when I took off the glove it was bleeding a lot, [...] I was worried about the results of the tests, [...] He had no confirmed diagnosis yet, [...] this patient". (P41)

"It was precisely during the administration of medication, [...] when I finished the procedure, I pulled the protective device and ended up piercing myself, [...] it bled a lot and it got pretty sore, [...] I was worried about the risk of contamination". (P18)

"[...] when puncturing a vein, [...] at the end of the puncture, an accidental slip-up took place, [...] the needle pierced my finger; it is terrifying, [...] we can contaminate ourselves and, you know, [...] have to take those medications that give many reactions". (P39)

According to the professional's perception of risk, the accident is a result of exposure to biological material. Also, the use of chemoprophylactics is indicated in these cases due to the possibility of exposure to HIV and the HCV. After the accident, this professional may adopt new attitudes toward minimizing exposure to risk. It is known that identifying health risks, not neglecting them, is a determining factor for preventing accidents.

The consequences of occupational exposure to blood and other bodily fluids are not restricted to infections but involve psychological trauma due to possible seroconversion, sexual behavior changes, relationships, and the effects of prophylactic drugs. ${ }^{11}$

With regard to the psychic dimension, the workers' perception of risk influences their behavior. The feelings experienced after the accident, immediate reactions, and suffering arise from the fear of contamination. Psychiatric symptoms and disorders have been increasingly observed.
In a study conducted in the emergency sector of a health care unit in Goiânia city, Goiás State, Brazil, the feelings experienced by health care workers after being involved in biological accidents were identified. Fear of contamination, insecurity, anger, and even tranquility were highlighted. Moreover, half of the participants reported that no consequences resulted from the accident. ${ }^{12}$

Herein, we found that the study participants expressed feelings of anger, fear, and guilt:

"I pierced my finger after collecting material for an arterial blood gas analysis, [...] I think I lacked more attention, [...] I got really angry because I always do this procedure in my routine". (P24)

"I went to measure the patient's blood glucose without a glove, [...] I became confused during the procedure, [...] I do not even know how it happened, [...] I ended up piercing myself, [...] He/she was a critically ill patient, [...] without a diagnosis yet, [...] I got terrified". (P37)

"I was puncturing a patient, [...] I warned her that I was gonna puncture her, [...] the patient was lucid, [...] I got upset because of that, [...] she pulled her hand, [...] the needle came out of her skin and hit my finger". (P41)

"I went to assist the nurse in a procedure, when I went to collect the blade (it was used on the patient), I cut my finger, he was suspected of having HIV, [...] I got desperate and cried a lot". (P25)

The participants reported feeling guilty and responsible for the accident because they felt negligent and reckless during the activities that triggered the accident. However, in addition to individual factors, there are institutional factors (working conditions, material resources, heavy workload, etc.) that contribute to the occurrence of accidents.

Another factor associated with the professionals' expectations is the need for training to better face the risk and consequently prevent work accidents. The injured professional's lack of knowledge about the appropriate conduct after the accident was highlighted, as observed in the following reports:

"My first move would be to find the nurse, then she would give me the right information". (P3)

"I know more or less because I have seen colleagues go through this situation, [...] it is horrible!!, [...] I still have questions". (P11) 
"We have to look for the occupational health care service, [...] I think that is it; there they will guide us, [...] you also have to notify the nurse on duty". (P12)

"At first, I would look for the nurse, [...] but I myself would not know how to act, [...] because we panic when we puncture or cut ourselves with the instrument used in patients, [...] we think that we can instantly get infected". (P21)

"Look, the rule is, [...] I think, [...] washing the place with soap and water, [...] notifying the nurse, [...] following the guidelines that are given to us, [...] many here do not know how to act correctly because they do not know these guidelines". (P36)

The managers' role in the care for the injured team member is fundamental for understanding the importance of primary care and the referral to the occupational health care service of the institution. Moreover, it makes prophylaxis guidance protocols available. Transferring workers to a sector in which they perform activities different from those that caused the accident may be a strategy capable of minimizing emotional distress. ${ }^{10}$

In the social context, accidents have work, family and social repercussions. According to literature, the consequences of work accidents for workers are: emotional distress, irritability, hostility, depression, cognitive disorders, sleep disorders, chronic alcoholism, post-traumatic stress disorder, etc. ${ }^{13}$

"[...] we have to be careful not to get injured and get some disease, [...] the worst thing is that you come home with bad news, [...] we have children and worry, right?" (P17)

"I think the worst thing about the accident is to tell the family about it, [...] my husband asks us to be very careful in dealing with these patients, [...] depending on the accident, we have to stay away and wait for the institution, and for the INSS, [...] I think so much about my children, [...] about transmitting diseases to them, [...] or becoming disabled". (P27)

"I am very careful when I am working with critically ill patients, [...] after the accident everything changed, [...] we are treated differently, [...] being unable to work is worse, [...] I think about my family, [...] I do not want them to suffer if I had a serious accident". (P19)

"[...] I think the accident changes our whole life, [...] even the way we live with our family, [...] you feel so down, [...] you feel disheartened. My biggest fear is to be unable to work and have no way to support my family". (P33)
For the interviewees, work accidents are life-changing events, since they may not work again, stopping them from fulfilling personal and family needs. Furthermore, this situation makes them seek social security benefits in order to fulfill basic needs.

In 2008, the Instituto Nacional do Seguro Social (INSS) [National Institute for Social Security] granted 377,001 new occupational accident benefits, including disability insurances and disability retirements due to work accidents. Of these, 13,078 were due to mental and behavioral disorders, representing the third largest cause of concession of work-related disability insurance. ${ }^{14}$ It is important to point out that work accidents have negative repercussions for workers, health care institutions, and society.

\section{Risk perception, strategies for minimizing risk exposure, and notification of health problems.}

Accidents with sharp instruments are considered one of the concerns among health care workers. Underreporting is an aggravating practice since it is not possible to know the actual number of cases occurring in institutions. Non-notification leads to the impossibility of knowing the reality. ${ }^{15}$

According to the ILO: "Statistics of reported accidents and illnesses are often incomplete, as non-notification is common, and official reporting requirements often do not cover all categories of workers"2,27.

A study conducted with 451 nurses of an urgency service showed that the prevalence of non-notification of work accidents involving biological material was $23.23 \%$. Moreover, the study pointed out that the main reasons for non-notification were lack of knowledge about the notification mechanism, fear of notifying cases to the manager, excessive bureaucracy during the process of filling out forms, and the fact that the accident was considered to have low risk. ${ }^{16}$

Nevertheless, notification of health problems must be made immediately, regardless of whether the worker was removed, as established by Decree No. 3,048/1999. ${ }^{17}$

However, the study findings showed that this conduct was not frequently found among the participants:

"I did not notify the accident, [...] I went to wash my finger and I continued doing my work, [...] I did not see any danger, no, [...] the blade was new. I know that every accident must be reported, [...] the very busy shift, [...] and a lot of things, we forget to inform, we end up neglecting it". (P4)

"All that was done was done right here (in the ICU), [...] I washed my hand and made a dressing; the patient was new in the ICU, and all his tests were negative, [...] but I also tested negative, [...] [...] I stayed calm, so I did not notify it, [...] I know I neglected it”. (P9) 
"Actually, I did not notify it to the CAT [...] the needle was sterile, and all the patient's tests were negative". (P29)

According to the Labor Ministry, every accident must be reported to the INSS through the CAT on the first working day after the accident. On the day of the accident, the worker must notify the Serviço de Segurança e Medicina do Trabalho (SESMT) [Safety and Occupational Medicine Service] of the Institution or Company and fill out the CAT form. This procedure serves as a means to ensure accident benefits or disability retirement. ${ }^{8}$

In this study, we observed that $60 \%$ of the interviewees did not notify the accident. Notification allows hospital managers to know risk situations and intervene with specific measures and actions, minimizing the economic and social effects of accidents on institutions. ${ }^{18}$

As a way to minimize risks, it is essential that the worker makes use of PPE. The Ordinance of the Gabinete do Ministro (GM) [Minister's Office] No. 3.214, June 8th, 1978, which established the Norma Regulamentadora [Regulatory Standard] No. 6 (NR-6) defines PPE as any device or product designed for personal use during work, protecting workers from safety and health risks. ${ }^{19}$

NR-6 reinforces the obligation of the service to provide quality PPE. Workers are responsible for using it only for the intended purpose, as well as for their safekeeping and conservation. Moreover, they should notify the employer of any damage or changes that make it unsuitable for use. ${ }^{20}$

According to the interviewees' reports, PPE is important and part of the work routine. However, some of the participants stated that it was relativized, that is, its use was conditioned by the professionals' needs and work demands to the detriment of the obligation to and purpose of the use:

"[...] sometimes I start an activity and when I realize it, I am without one of them (PPE); the correct thing is to make continuous use of them, right?" (P31)

"[...] if it is not here, I will seek it in other sectors, [...] the thing is, I do not work without PPE, [...] it does not matter whether they like it or not, but I do not work". (P37)

"I confess, [...] I do not use it much, [...] when it is calm, we put on the protective gear, [...] there are very busy shifts, [...] you do things without protecting yourself, [...] and it goes on until the end of the shift".

"Here in the ICU, we know we have to make use of this equipment, but sometimes it is so rushed, [...] I always put the mask on right away, [...] When I visit the patient, I put the glove on, [...] we have to protect ourselves, right?" (P31)

A study conducted with professionals working in the surgical center of an institution located in the United States of America showed that $51.4 \%$ of the participants suffered accidents with sharp instruments during work, $62.1 \%$ were exposed to biological fluids and $39.6 \%$ were exposed to both. It was highlighted that $14.1 \%$ of the workers who suffered accidents with sharp instruments and $5 \%$ of those exposed to biological fluids were not using PPE at the time of the accident. ${ }^{21}$

According to literature, the reasons for not using PPE are as follows: lack of PPE or impossibility of finding PPE with the right size, difficult access, lack of financial resources, organizational structure, haste, belief that no disease will be contracted, resistance, improper use, interference at work, inability to work and ignorance of the preventive role of PPE. ${ }^{22,23}$

In this study, the interviewees pointed out that there was a shortage of PPE. Also, they reported feeling discomfort while using it:

"[...] sometimes it feels like a suffocating sensation, [...]

I have to take the mask off for a while". (P44)

"[...] I have already carried out procedures without the protective apron, due to the heat". (P16)

"They demand that we use PPE, [...] sometimes we do not have PPE for everyone”. (P22)

"[...] the fact that we do our part is not enough, [...] the institution has to provide enough PPE for the whole team in the three shifts, [...] I have worked here for a while when there was a shortage of gloves, [...] it is absurd!! And sometimes the gloves are oversized. It bothers me". (P 17)

In relation to the strategies capable of minimizing work accidents, compliance with biosafety standards, such as the use of PPE, hand hygiene, confirmation of immunization, correct disposal of sharp materials, and attention to the clinical activity being performed, should be encouraged and emphasized as basic measures to protect workers' health as well as prevent and minimize work accidents. ${ }^{24,25}$

\section{Importance of immunization as an action for health prevention}

Work accidents among health care professionals are one of the main causes of infection with hepatitis $B$. According to the Brazilian Ministry of Health, the risk of HIV infection is $0.3 \%$ after skin exposure and $0.9 \%$ after mucosal exposure. The risk of HBV infection is $6 \%$ to $30 \%$, reaching $40 \%$ if prophylactic measures are not started. ${ }^{26,27}$

The risk of HCV infection is $1.8 \%$ involving a source patient with HIV, reaching up to $7 \%$. In addition to HIV, hepatitis B, and hepatitis $C$, injuries from sharp instruments are capable of transmitting more than 20 types of pathogens. 
NR-32 requires institutions to provide free vaccination against tetanus, diphtheria, hepatitis B, yellow fever, influenza, etc. 8 In this study, it was observed that the interviewees were concerned about maintaining an updated vaccination schedule as a preventive measure. The reports also showed that the workers feared being infected after suffering an accident, especially with $\mathrm{HBV}, \mathrm{HCV}$, and HIV.

"Yes, I am immune to hepatitis B, tetanus, [...] and others that I cannot remember, but I am up to date with my schedule, [...] I do not want to take that risk ever, [...] I had a colleague who got infected, [...] contracted the hepatitis $C$ virus, [...] that is horrible!!!” (P4)

"[...] I really care about that!!!, [...] I am vaccinated against yellow fever, hepatitis $B$, tetanus and tuberculosis, [...] we have to take care of ourselves, you know, [...] I have to be up to date with this schedule, [...] I live in constant fear of catching disease due to carelessness". (P6)

"I am immune to yellow fever, tetanus, hepatitis B and H1N1, [...] I get very worried, [...] I am afraid to contaminate myself, [...] you know, our lives are in constant risk, [...] health care worker". (P19)

"I was immunized against hepatitis B and tetanus, [...] last year (2014) [...] I got some booster doses, [...] actually, I am up to date with my schedule, [...] I want to feel safe”. (P20)

Vaccinating professionals against Hepatitis B and following standard guidelines for preventing body fluid exposure reduces the occurrence of hepatitis B among health care workers. ${ }^{28}$

\section{Concerning the continuing education actions}

The following measures to prevent and control accidents in the hospital environment were highlighted: workers' awareness; the existence of the Comissão Interna de Prevenção de Acidentes (CIPA) [Internal Commission for Accident Prevention], Comissão de Controle de Infecção Hospitalar (CCIH) [Commission for Hospital Infection Control], Programa de Prevenção de Riscos Ambientais (PPRA) [Environmental Risk Prevention Program] and Programa de Prevenção de Riscos Ocupacionais (PPRO) [Occupational Risk Prevention Program]; periodic training for employees; supply of PPE; and adequacy of the physical and functional structure. ${ }^{29}$

In this sense, health education should be characterized by proposals for changes during activities carried out in teaching institutions, visualizing the policies on workers' health regarding the training of nurses as well as other members of the nursing team. ${ }^{7}$

Continuing health education consists of personal development that must be enhanced in order to promote the acquisition of new knowledge, concepts, and attitudes, as well as promote the subjects' specific technical training. Thus, intrinsically, a capacity to be developed, a competence, is the constant learning present in all of the subject's relations. ${ }^{30}$ Guiding actions and training programs are present in the daily practice of the professional.

In this sense, the participants were asked about attendance to training courses or interactive workshops on work accidents in the ICU mainly involving sharp instruments. The participants reported needing to receive guidance in safely and adequately dealing with these instruments during their routine so that the occurrence of these events could be minimized. Also, actions that better qualify the care provided by these workers and minimization of risks were considered to be important according to the interviewees' statements. However, it was not possible to clearly understand the best strategy that had to be developed in order to develop a safe environment and make the professionals reflect on their work process.

"Continuing education would help a lot, [...] it would keep us constantly informed; it is important that continuous planning continue to be carried out in the ICU”. (P9)

"I think that the lectures are of great contribution; using them as a means of erasing any doubts, [...] and the training, it would be a tool for fighting, still, against old conducts; we need, daily, or periodically, new information, [...] today, everything is renewed quickly". (P26)

"Continuing education, periodically, is a positive means of minimizing the risks of accidents with these instruments within the ICU, [...] and training is essential". (P32)

"Many accidents happen because of bad habits, [...] I think we have to put an end to them, [...] to establish safe behavior, [...] both lectures and training, they will only have satisfactory results if there is an involvement of all, [...] if there are commitment and responsibility. So, there may be a chance for changes". (P34)

Periodic lectures, [...] training taking place near beds, [...] when you experience the reality, it is easier for you to absorb the information, [...] and everyone should participate, with the same interest, [...] so everyone wins". (P41)

\section{CONCLUSION}

This study sought to understand the intensive care nursing team's perception of accidents with sharp instruments in a large public hospital in São Luis city. It is known that access to health information by workers exposed to occupational risks enables the identification and definition of risk control strategies aiming to minimize the occurrence of accidents. 
In this study, it was verified that the risks are inherent to professionals' work routines. Nevertheless, they still were working under stressful conditions involving extensive workload and lack of material resources. Moreover, there was not enough PPE for the workers.

With regard to the concept of work accident, it was regarded by the interviewees as a random event, an act of negligence, or even an event related to the work routine. Although there are risks inherent to any health work process and the course of life, they cannot be viewed as natural events and/or neglected. Health risk prevention strategies should be constantly implemented and be able to minimize health professionals' and patients' exposure. Therefore, this is a challenge that deserves permanent attention from managers, professionals, and users of health services.

Concerning the workers' perception of the use of sharp instruments in the ICU, it was found that the use of needles and blades by professionals is common. These instruments were properly disposed of in containers as recommended by health legislation. However, the location of these containers was inadequate and probably favored the occurrence of accidents. Thus, intervention is needed to place the disposal container in an easily accessible place aiming at the safety of the nursing team. It is recognized the need for adequate management of solid residues according to their characteristics. This management involves aspects related to generation, segregation, conditioning, collection, storage, transport, treatment, and final disposal, aiming at protecting public health and the environment.

With regard to expectations about personal and professional life as a result of the accident, fear of being infected was observed. This fear is magnified in the face of the possibility of illnesses that in the long run may become incapacitating and capable of changing plans. This context highlights the urgent need for training actions to be developed by the Occupational Medicine Services since more qualified workers tend to minimize exposure to risks and undertake coordinated actions to deal with accidents.

This study made it clear that the interviewees recognized the importance of using PPE, but do not always make use of it, which can contribute to the occurrence of accidents. The findings also revealed that the non-notification of health problems was a common practice among the workers. Nonetheless, notification is indispensable, since it makes it possible to know the actual number of work accidents and undertake control actions to protect hospital workers.

It is highlighted that all the interviewees had concerns about keeping an updated vaccination schedule so that they can remain immune to hepatitis B and other diseases. Nevertheless, the incentive for immunization should continue as a preventive measure.

As far as continuing education are concerned, it is not present in the work routine of the interviewees. Nevertheless, they reported the relevance of continuing education because it leads to more qualified work. The study results indicated the need for periodic training during the work process. The interviewees reaffirmed that these actions expand professional knowledge and serve as an important tool for preventing work accidents, especially involving sharp instruments.

It was possible to reaffirm that although nurses adopt a modern practice while providing care, they also should take care of their health.

Bearing in mind the afore mentioned, this study was conducted to promote reflection on work accidents among nursing professionals. Its findings may be used along with those from other studies to reaffirm the development of a plan of action that is specific to health care professionals, especially those involved in welfare activities. It is necessary to implement strategies that ensure the professionals' right to health, safe actions, and minimization of biological, chemical, physical, or emotional risks. These risks have been contributing to the occurrence of disease among health care workers. Work must be perceived as a healthy activity capable of fulfilling professional and personal needs without causing suffering. Hence, the relationship between health and work must enable the transformation of social reality.

\section{REFERENCES}

1. Brasil. MF, MTE, 2015. Anuário Estatístico de Acidentes do Trabalho: AEAT 2015 / Ministério da Fazenda. vol. 1 (2009). Brasília: MF. 2015; $991 \mathrm{p}$.

2. Arieiro VMQ. Subnotificação de acidentes de trabalho de enfermeiros do serviço de urgência. Instituto Politécnico de Viana do Castelo. Escola Superior de Saúde. Viana do Castelo-Portugal, 2015. Dissertação de Mestrado em Enfermagem médico-cirúrgica.

3. Relatório Global da OMS. Global Hepatitis Report. Geneva: World Health Organization. Relatório Global da OMS. 2017. Available from: www.who.int/mediacenter/factsheets/fs204/en.

4. Peixoto MKAV. Perspectiva para o trabalho em equipe de enfermagem na Unidade de Terapia Intensiva. Faculdade de Enfermagem da Universidade Federal de Goiás. 2012. Dissertation. Programa de PósGraduação em Enfermagem.

5. Cavalcante AAC, Enders CB, Menezes PMR, Medeiros MS. Riscos ocupacionais do trabalho em enfermagem: uma análise contextual. Ciênc Cuid Saúde. 2006; 5(1): 88-97.

6. Mastroeni MF. A difícil tarefa de praticar a biossegurança. São Paulo: Ciência NE Cultura. 2008; 60(2): 4-5.

7. Simão SAF, Soares CRG, Souza V, Borges RAA, Cortez EA. Acidentes de trabalho com material perfurocortante envolvendo profissionais de enfermagem de unidade de emergência hospitalar. Rev Enferm UERJ. 2010; 18(3): 400-4.

8. Brasil. Ministério do Trabalho e Emprego. Portaria GM $n^{\circ} 485$, de 11 de novembro de 2005. DOU de 16/11/05-Secão 1. Aprova a Norma Regulamentadora no 32 de Segurança e Saúde no Trabalho em Estabelecimento de Saúde. Última alteração/atualização: Portaria GM n 1.748 , de 30 de agosto de 2011. Available from: <https://www. anamt.org.br/portal/2011/03/03/portaria-no-1-748-de-30-de-agostode-2011/>

9. Brasil. Resolução - RDC/ANVISA n 306, de 7 de Dezembro de 2004. Dispõe sobre o Regulamento Técnico para o gerenciamento de resíduos de serviço de saúde.

10. Steffens AP. Acidentes de Trabalho com perfurocortantes: repercursões na vida dos trabalhadores. São Paulo: Andreoli, 2008; 128p.

11. CanalliI RTC, Tokico MM, Hayashidall M. Prevenção de acidentes com material biológico entre estudantes de enfermagem; Rio de Janeiro: Rev Enferm UERJ. 2011; 19(1):100-6.

12. Damaceno AP, Pereira MS, Souza ACS, Tipple AFV, Prado MA Acidentes ocupacionais com material biológico: a percepção do profissional acidentado. Rev Bras Enferm. 2006; vol.59, n.1, p.72-7. 
13. Cohidon C, Diène E, Carton M, Fatras J, Goldberg M, Imbernon E. Mental health of workers in Toulouse 2 years after the industrial AZF disaster: first results of a longitudinal follow-up of 3,000 people. Social Psychiatry and Psychiatric Epidemiology. 2009; 44, 784-91.

14. Brasil. Ministério da Previdência Social, Empresa de Tecnologia e Informações da Previdência Social. Brasília: Anuário Estatístico da Previdência Social. 2009; 17: MPS/DATAPREV.

15. Dias AC, Vicente AP, Matos A, Madeira CP, Santos CS, Simões GV, et al. Acidentes de trabalho e doenças profissionais: Orientações técnicas. Lisboa e Vale do Tejo: Administração Regional de Saúde de Lisboa e Vale do Tejo, IP, 2013. Available from: <http://www.dgs.pt/delegadode-saude-regional-de-lisboa-e-vale-do-tejo/paginas-acessorias/ ficheiro-externos/saude-ocupacional/orientacoes-n-3-acidentes-edp-pdf.aspx..s/n>

16. Facchin LT, Silva SEM. Prevalência de não notificação de acidentes com material biológico pela equipe de enfermagem de um hospital de urgência; Ribeirão Preto. 2010.

17. Brasil. Decreto No 3.048, de 6 de maio de 1999. Aprova o Regulamento da Previdência Social, e dá outras providências. Art. $1^{\circ}$ A seguridade social compreende um conjunto integrado de ações de iniciativa dos poderes públicos e da sociedade, destinado a assegurar o direito relativo à saúde, à previdência e à assistência.

18. Bakkea HA, Araújo NMC de. Acidente de trabalho com profissionais de saúde de um hospital universitário. Universidade Federal da Paraíba. Brasil. Produção. 2010; v.20, n.4, p.669-76. Available from: www.scielo.br/pdf/prod/v20n4/aop00040109.pdf >

19. Brasil. Ministério do Trabalho. Portaria 3.214, de 8 de junho de 1978. Dispõe segurança e medicina do trabalho. Última atualização/ alteração: Portaria SIT no 292, de 8 de dezembro de 2011.

20. Spagnuolo RS, Baldo RCS, Guerrini IA. Análise epidemiológica dos acidentes com material biológico registrados no Centro de Referência em Saúde do Trabalhador - Londrina/PR. Rev Bras Epidemiol. 2008; 11(2): 315-23

21. Gailiene G, Cenekiene R. Professional biological risk factors of health care workers. Medicina. 2009; vol.45, nº7, p.530-36.

22. Moura JP. A adesão dos profissionais de enfermagem às precauções de isolamento na assistência aos portadores de microrganismos multirresistentes Ribeirão Preto. Universidade de São Paulo, Escola de Enfermagem de Ribeirão Preto, 2004. Dissertação de Mestrado em Enfermagem.

23. Tipple AFV, Souza ACS, Almeida ANG, Sousa SB, Siqueira KM Acidente com material biológico entre trabalhadores da área de expurgo em centros de material e esterilização. Acta Sci Health Sci. 2004; 26(2): 271-8.

24. Andrade Neto EP, Dutra CS, Lima V, Goes P. Prevalência de acidentes ocupacionais e perfil de vacinação contra Hepatite B entre estudantes e profissionais da odontologia: um estudo piloto. Arq Odontol. 2013; Mar v. 49, n. 1, p. 32-8.

25. Santos JAD, Costa FM. Hepatite B: fatores de risco e atitudes profiláticas de estudantes e profissionais da saúde. Saude e Pesqui. 2014; v. 7, n. 2, p. 341-51.

26. Brasil. Ministério da Saúde (BR). Doenças relacionadas ao trabalho: manual de procedimentos para os serviços de saúde. Bases técnicas para o controle dos fatores de risco e para melhoria dos ambientes e das condições de trabalho. Brasília-DF; p. 580, 2001; STE.

27. Martins RJ, Moimaz SAS, Sundefeld MLMM, Garbin AJI, Gonçalves PRV, Garbin CAS. Adesão às precauções padrão sob o prisma do Modelo de Crenças em Saúde: a prática de reencapar agulhas. Ciênc Saúde Coletiva. 2015; v. 20, n. 1, p. 193-8.

28. Nishide VM, Benatti MCC. Riscos ocupacionais entre trabalhadores de enfermagem de uma unidade de terapia intensiva. São Paulo, USP: Rev Esc Enferm. 2004; v.38, n.4, p.406-14. Available from: http://www. scielo.br/scielo.php?pid=SOO80_62342004000400006\&script.

29. Lubenow JAM, Moura MEB, Nunes BMVT, Figueiredo MLF, Sales LC. Representações sociais dos acidentes com materiais perfurocortantes. Rev Lat Americ de Enferm. 2012; 20(6): 1176-185.

30. Sardinha PL, Cuzatis GL, Dutra CT, Tavares CMM, Dantas CAC Antunes CE. Educação Permanente em Saúde: desafio ambicioso e necessário. Rev Enfermería Global 2013; Enero n. 29.

Received in: 19/06/2018

Required revisions: 25/02/2019

Approved in: 18/05/2019

Published in: 01/07/2020

\section{Corresponding author}

Sandra Regina Santos

Address: V-13, Qd.15, Parque Shalon

São Luís/MA, Brazil

Zip code: $65.073-120$

Email address: sandra.reginasantos@yahoo.com.br Telephone number: +55 (98) 3226-0549 